\title{
Forms and usage of indigenous knowledge as tools to improve the quality of life in Idemili South Local Government Area Anambra State, Nigeria
}

\author{
${ }^{1}$ G. N. Lazarus \& ${ }^{2}$ I. Jinadu \\ ${ }^{1 \& 2}$ College Library \\ Adeniran Ogunsanya College of Education \\ Oto/Ijanikin, Lagos, Nigeria \\ E-mail: ${ }^{1}$ nnekalazarus@gmail.com, ${ }^{2}$ jinaduliasu@gmail.com \\ Cell: ${ }^{1}+2348034748419 ;{ }^{2}+2348055678602$
}

\begin{abstract}
The study investigated the forms of indigenous knowledge (IK) and how their utilization determines the quality of life of people in Idemili South Local Government Area of Anambra State, Nigeria. While the main objective of the research was to investigate how the forms and usage of indigenous knowledge improve the quality of life of people in Nigeria, the specific objectives were: to identify the forms of indigenous knowledge in Nigeria, examine the use of indigenous knowledge in Nigeria and determine the quality of life of rural people in Nigeria. Adopting a survey research design, a multi-stage sampling technique was used to select 287 rural dwellers whose age range was between 20-65years from seven (7) communities as respondents for the study. The questionnaire had three sections A-C. The questions were tested for validity and reliability using the Cronbach's alpha test. One of the major findings was that appropriate use of the identified forms of IK significantly improve the quality of life of rural people. The study recommended, among others, that libraries and librarians should endeavor to preserve and disseminate IK in Nigeria in order to rekindle interests in indigenous knowledge as a research domain intended to improve the quality of life of the rural people.
\end{abstract}

Keyword: Forms of indigenous knowledge, IK, Usage of indigenous knowledge, Quality of life, Anambra State, Nigeria

\section{Introduction}

The term quality of life is also referred to as well being. Well-being is used to refer to objective life conditions that are applicable to a population generally while quality of life is limited to individual's subjective assessments of live (Theofilou, 2013).Quality of life is an individual's perception of his or her position in life in the context of culture and value systems in which he or she lives and in relation to his or her goals, expectations, and concerns incorporating physical health, psychological state, and level of independence, social relations, personal beliefs and relationship to salient features of the environment. Quality of life can also be described as a subjective evaluation which is embedded in a cultural, social and environmental context (World Health Organization, 2002).

According to the European Commission (2015), quality of life can be measured by a lot of indicators such as material living conditions, productive or main activity, income, personal and family life, leisure and social interactions, economic and physical safety. In addition, quality of life can be determined by the general characteristics of the community based ongovernance and basic rights, natural and living environment and overall experience of life. According to Zaid and Poopola (2010), the domains that are selected as indicators of quality of life are: educational level, health, income, occupation, social relationship, housing, neighborhood and family life. Quality of life 
G. N. Lazarus and I. Jinad: Forms and usage of indigenous knowledge as tools to improve the quality of life in Idemili South Local Government Area Anambra State, Nigeria

of people is connected to the forms of indigenous knowledge (IK) and its uses.

Indigenous knowledge is based on social, physical and spiritual understandings which have informed the people's survival and contributed to their sense of being in the world. Africa has a rich body of indigenous knowledge which, for many decades, has been handed down by word of mouth from generation to generation (Grey, 2014). Such indigenous knowledge has traditionally played a vital role in the area of agriculture, animal and human health, natural resource management, education, economic and other social activities. Indigenous knowledge (IK) has become an accepted term which includes the expressions, practices, beliefs, understandings, insights, and experiences of indigenous groups generated over centuries of profound interactions with a particular territory (Grey, 2014).According to InterAgency Support Group (IASG, 2014), indigenous knowledge is the innovations and practices of people around the world. In addition, it is developed from experiences gained over the centuries and adapted to cultures and environment.

Indigenous knowledge covers original expressions of local knowledge as well as the complex process of access, interpretation, synthesis and repackaging of local and global knowledge. It also encapsulates several centuries of adaptive evolution. By so doing, the vagaries of climate, availability of land and water and the basic needs of people and their animals for food, shelter and health have been amalgamated in a system which has allowed society to exist and develop. Indigenous knowledge is a complete knowledge system with its own concepts of epistemology and its own scientific and logical validity (Magni, 2016). Indigenous knowledge represents generations of creative thoughts and actions within each individual community. As a result of this, it struggles with an ever-changing set of conditions and problems. This strong contextual and cultural connection has made indigenous knowledge an essential part of people's lifestyle as it provides the necessary means of survival. This research therefore identified the forms of indigenous knowledge as tools to improve the quality of life in Nigeria.

\section{Statement of the problem}

Quality of life of rural people is not just a physical well-being of an individual but is the social, emotional, and cultural wellbeing of the whole community in which each individual is able to achieve their full potential thereby bringing about life satisfaction and fulfillment of their community. Despite the significance of the forms of indigenous knowledge existing in Idemili South Local Government Area of Anambra State, Nigeria, IK has seemingly been undermined and somehow neglected and this has a negative impact on the quality of their life in terms of health, cultural values, communication and language. This is particularly important for addressing the issue of the forms and usage of indigenous knowledge to improve the quality of life of rural people. Thus, this research investigated how the utilization of indigenous knowledge determined the quality of life of people in Idemili South Local Government Area of Anambra State.

\section{Objectives of the study}

The main objective of this research was to investigate how the forms and usage of indigenous knowledge improves the quality of life of people in Idemili South Local Government Area of Anambra State, Nigeria. The specific objectives were to: 
G. N. Lazarus and I. Jinad: Forms and usage of indigenous knowledge as tools to improve the quality of life in Idemili South Local Government Area Anambra State, Nigeria

1) identify the forms of indigenous knowledge in Nigeria;

2) examine the use of indigenous knowledge in Nigeria; and

3) determine the quality of life of rural people in Nigeria

\section{Research questions}

1) What are the forms of indigenous knowledge in Idemili South Local Government Area of Anambra State, Nigeria.?

2) What are the uses of indigenous knowledge in Idemili South Local Government Area of Anambra State, Nigeria?

\section{Research hypothesis}

$\mathrm{Ho}_{1}$ : Forms of indigenous knowledge does not significantly influence the quality of life of people in Idemili South Local Government Area of Anambra State, Nigeria.

\section{Literature review}

Norudin, Zainudin and Che-Haspu (2013) stated that quality of life is described as having significant value for living and adaptation, complying with requirements or standard categorically. This implies that quality of life expresses a mode of living adapted by an individual, group, nation, or Commonwealth of Nations. Quality of life therefore takes shape within the interrelationship of economic, political, cultural and religious frameworks, patterns and discourse. In Sociology as a discipline, quality of life is understood as subjective understanding of well-being taking into account individual need and understanding. In Economics, it is the standard of living, in Medicine; it is the ratio of health and illness with the factors influencing healthy lifestyles. Idris, Shaffril, Yassin, Samah, Azimi and Samah (2016) postulated that a country is not rated as developed by its economic achievements and rapid progress but by the quality of life and well-being of its people. Idris et al (2016) further clarifies that there exists objective and subjective quality of life. The objective quality of life in their opinion reveals itself in a person's ability to adapt to the values of a culture and describes little about that person's life such as social status and symbols which make one to be a member of that culture.

Measuring quality of life means determining the value of people's lives and also to maintain or enhance the things that already, or could, add quality to people's lives. Camfield (2005) conducted a study on how different people characterize quality of life in Bangladesh, Ethiopia, Thailand and Peru and found out that the basic ingredients of a good life (quality of)are very similar, such as having a partner, a family, a good home, a pleasant environment and enough money or other resources to meet the daily needs of the family.

Veenhoven (2010) in his study found that most of the world's ideas of life getting better were described as situations where, on average, citizens live comfortably, more social evils are abated and untimely deaths are greatly reduced. Gregory-little and Watts (2009) emphasized that quality of life does not simply refer to income related living standards of individuals but a wider concept that also includes the surrounding environment, physical and mental health, education, leisure and recreation. Such reasoning reaches back to Maslow classical hierarchy of needs (Maslow, 1943). Today, the basic human needs in developed nationsthe physiological (such as food, sleep, homeostasis or excretion) and safety-related (such as security, health or employment) needs that previously were the main target areas of governance are no longer sufficient. They are now being complemented with higher levels of human well-being such as 
G. N. Lazarus and I. Jinad: Forms and usage of indigenous knowledge as tools to improve the quality of life in Idemili South Local Government Area Anambra State, Nigeria

belonging, self-esteem and selfactualization. Such development is in line with the now broadly accepted social sustainability paradigm (United Cities and Local Governments (UCLG) (2008).Indigenous and traditional knowledge are important to the entire humanity as the well-spring from which all knowledge originates. Riser (2012) postulated that the complexity of social, economic, political, and environmental sustainability has prompted scholars, political leaders, and theologians in every continent to search for sources of knowledge that will provide the best solution to improve the quality of life of everyone and everything on the planet. However, some major indicators of quality of life of people are: educational level, occupation, income, health, housing and neighborhood, family life, governance, social status and safety.

\section{Methods}

The research adopted a descriptive research design. The population consisted of the target communities in Idemili South Local Government Area of Anambra State made up of seven (7) communities with a total of 237, 900 people. The population included the elderly and youths whose ages range between twenty (20)and sixty-five (65) years. A multi-stage sampling technique was used to select appropriate sample size for this work. A structured questionnaire titled "Forms of Indigenous Knowledge as Tools to Improve the Quality of Life Questionnaire (FIKIQLQ)" was used as instrument to collect data from the respondents. The questionnaire has two sections $\mathrm{A}$ and $\mathrm{B}$. Section A focused on items on forms of indigenous knowledge found in the communities. Values were attached to Likert type scale as follows: Strongly Agree ( $\mathrm{SA}=$ 4Points), Agree ( $\mathrm{A}=3$ Points $)$, Disagree $(\mathrm{D}=$ 2Points), Strongly Disagree ( $\mathrm{SD}=1$ Point).
Section B was intended to examine the usage of indigenous knowledge in the various communities. Values were attached to the Likert type scale as follows: Strongly Agree ( $\mathrm{SA}=$ 4Points), Agree ( $\mathrm{A}=3$ Points), Disagree ( $\mathrm{D}=2$ Points), Strongly Disagree ( $\mathrm{SD}=1$ Point). The questions were tested for validity and reliability using the Cronbach's alpha test. The questionnaire was distributed and collected by the researcher. The questionnaire was analyzed using descriptive analysis such as frequency count, percentage distribution, mean and standard deviation.

\section{Result and discussion}

This presented the results of data analysis, the interpretation and discussion of findings relating to the forms and usage of indigenous knowledge as tools to improve the quality of life in idemili south Local Government Area Anambra State, Nigeria . A total of 384 copies of questionnaire were administered to the respondents and all were retrieved. Out of three hundred of eightyfour copies returned, two hundred and eighty-seven (287) of the returned questionnaires were useful. This gave a response rate of $74.7 \%$ which was considered adequate for this study.

\section{Research Question 1: What are the forms of indigenous knowledge available in Idemili South Local Government Area of Anambra State?}

This research question is answered with the data in Table 2.

Table 1 presents result of the various forms of indigenous knowledge available in the various communities. The percentage of respondents and their responses were presented in the same box for ease of reference. That is, the respondents who strongly Agree (SA) and agreed (A) on the items were added for accuracy. On the forms 
G. N. Lazarus and I. Jinad: Forms and usage of indigenous knowledge as tools to improve the quality of life in Idemili South Local Government Area Anambra State, Nigeria

of indigenous knowledge available in the communities, results show that the respondents agreed that Folksongs were types of stories available in the rural communities $(253,88.2 \% ; \bar{x}=3.55)$, Proverb $(250,87.1 \% ; \bar{x}=3.43)$, Folktales $(247,86.1 \% ; \bar{x}=3.40)$ and Poetry $(245$, $85.4 \% ; \bar{x}=3.38$ ). This result implies that folksongs, proverbs, folktales and poetry were the forms of indigenous knowledge available in the communities.

On the forms of ceremonies available in the communities, the result reveals that the respondents indicated traditional marriage $(266,92.7 \% ; \bar{x}=3.73)$, New yam festival $(272,94.8 \% ; \bar{x}=3.65)$, Masquerade day $(257,89.5 \% ; \bar{x}=3.64)$, Harvest of crop $(249,89.5 \% ; \bar{x}=3.62)$, rituals $(249,86.7 \% ; \bar{x}=3.55)$ and wrestling $(246,85.7 \% ; \bar{x}=3.51)$ as major ceremonies available and being carried out in their respective villages. Based on the result, it could be inferred that traditional marriage, new yam festival, masquerade day, harvest of crops, rituals and wrestling were the highest among the ceremonies available and being carried out by the respondents. The possible implication to be drawn from the results was that traditional marriage, new yam festival, masquerade day, harvest of crop, rituals and wrestling were the forms of ceremonies commonly available in the communities.

Research question 2: What are the usage of indigenous knowledge in Idemili South Local Government Area of Anambra State? This research question is answered with the data in Table 2.

Table 2 shows some of the uses of indigenous knowledge in the rural communities. The percentage of respondents and their responses were presented in the same box for ease of reference. That is, the respondents who strongly Agree (SA) and agree (A) in the items were added for accuracy. On the utilization of indigenous knowledge, results show that processing and preserving yam, cocoyam, plantain in dry form and/or grind them into flour for traditional dishes $(206,71.8 \% ; \bar{x}=3.09)$ and planting of lemon grass to control or expel termites $(218,75.9 \% ; \bar{x}=3.06)$ were used in agriculture. The result implies that the rural people use indigenous knowledge for processing and preserving yam, cocoyam, and plantain in dry form and/or grind them into flour for traditional dishes as well as planting of lemon grass to control or expel termites. Results also revealed that a higher percentage of the respondents agreed that they use indigenous surgeons, combine surgery and herbs to deliver pregnant women of their babies $(235,81.9 \% ; \bar{x}=$ 3.43 ) and making incision on the swollen part of the body in a bid to get rid of bad water or blood after which herbs are applied on the body $(233,81.2 \% ; \bar{x}=3.33)$. It was also revealed that rural people use obialu$o f u u($ scent leaf) and chewing of 'onugbu(bitter leaf) to quell problems (226, $78.8 \% ; \bar{x}=3.17)$. This result implies that rural people use indigenous knowledge in traditional Medicine practice in the communities.

In order to achieve the objectives of this study, one hypothesis was tested.

Ho1: Forms of indigenous knowledge does not significantly influence the quality of life of people in Nigeria.

This hypothesis is tested with the data in Table 3. 
G. N. Lazarus and I. Jinad: Forms and usage of indigenous knowledge as tools to improve the quality of life in Idemili South Local Government Area Anambra State, Nigeria

Table 1: Forms of indigenous knowledge

\begin{tabular}{|c|c|c|c|c|c|c|}
\hline Stories & $\mathrm{SA}(\%)$ & $\mathrm{A}(\%)$ & $\mathrm{D}(\%)$ & $\operatorname{SD}(\%)$ & Mean & Std \\
\hline Folksongs & $169(58.9)$ & $84(29.3)$ & $28(9.8)$ & $6(2.1)$ & 3.4 & .755 \\
\hline Proverb & $167(58.2)$ & $83(28.9)$ & $30(10.5)$ & $7(2.4)$ & 3.4 & .776 \\
\hline Folktales & $161(56.1)$ & $86(30.0)$ & $33(11.5)$ & $7(2.4)$ & 3.4 & .786 \\
\hline Poetry & 177(61.7) & $68(23.7)$ & $16(5.6)$ & $26(9.1)$ & 3.3 & .945 \\
\hline Legend & $149(51.9)$ & $90(31.4)$ & $40(13.9)$ & $8(2.8)$ & 3.3 & .817 \\
\hline Myths & $151(52.6)$ & $89(31.0)$ & $35(12.2)$ & $12(4.2)$ & 3.3 & .846 \\
\hline Incantation & $151(52.6)$ & $84(29.3)$ & $41(14.3)$ & $11(3.8)$ & 3.3 & .855 \\
\hline Weighted Mean & & & & & 3.3 & \\
\hline \multicolumn{7}{|l|}{ Ceremonies } \\
\hline Traditional marriage & $233(81.2)$ & $33(11.5)$ & $18(6.3)$ & $3(1.0)$ & 3.7 & .622 \\
\hline New yam (Ifejioku) & $211(73.5)$ & $61(21.3)$ & $5(1.7)$ & $10(3.5)$ & 3.6 & .688 \\
\hline Masquerade day & $216(75.3)$ & $44(15.3)$ & $23(8.0)$ & $4(1.4)$ & 3.6 & 689 \\
\hline Harvest of crop & $215(74.9)$ & $42(14.6)$ & $22(7.7)$ & $8(2.8)$ & 3.6 & .748 \\
\hline Rituals & $215(74.9)$ & $34(11.8)$ & $18(6.3)$ & $20(7.0)$ & 3.5 & .891 \\
\hline Wrestling & 197(68.9) & $49(17.1)$ & $31(10.8)$ & $10(3.5)$ & 3.5 & .823 \\
\hline Songs & $192(66.9)$ & $47(16.4)$ & $40(13.9)$ & $8(2.8)$ & 3.4 & .835 \\
\hline Music and dance & $184(64.1)$ & $64(22.3)$ & $19(6.6)$ & $20(7.0)$ & 3.4 & .894 \\
\hline Proverbs & $164(57.1)$ & $85(29.6)$ & $36(12.5)$ & $2(0.7)$ & 3.4 & .735 \\
\hline Poems & $158(55.1)$ & $96(33.4)$ & $26(9.1)$ & $7(2.4)$ & 3.4 & .756 \\
\hline Parables & $163(56.8)$ & $77(26.8)$ & $40(139)$ & $7(2.4)$ & 3.3 & .814 \\
\hline Idioms & $160(55.7)$ & $80(27.9)$ & $30(10.5)$ & $17(5.9)$ & 3.3 & .889 \\
\hline Folklore & $144(50.2)$ & $98(34.1)$ & $35(12.2)$ & $10(3.5)$ & 3.3 & .818 \\
\hline Anecdote & $134(46.7)$ & $105(36.6)$ & $43(15.0)$ & $5(1.7)$ & 3.2 & .780 \\
\hline Weighted Mean & & & & & 3.4 & \\
\hline \multicolumn{7}{|l|}{ Values } \\
\hline $\begin{array}{l}\text { Guides in decision } \\
\text { making among the } \\
\text { rural people }\end{array}$ & $189(65.9)$ & $60(20.9)$ & $26(9.1)$ & $12(4.2)$ & 3.4 & .827 \\
\hline $\begin{array}{l}\text { Standard for } \\
\text { evaluation of } \\
\text { behavior of the rural } \\
\text { people }\end{array}$ & $175(61.0)$ & $70(24.4)$ & $36(12.5)$ & $6(2.1)$ & 3.4 & .791 \\
\hline $\begin{array}{l}\text { Holding human life } \\
\text { as sacred }\end{array}$ & $172(59.9)$ & $68(23.7)$ & $37(12.9)$ & $10(3.5)$ & 3.4 & .842 \\
\hline $\begin{array}{l}\text { Murder and suicide } \\
\text { among its members }\end{array}$ & $175(61.0)$ & $65(22.6)$ & $29(10.1)$ & $18(6.3)$ & 3.3 & .904 \\
\hline Weighted Mean & & & & & 3.4 & \\
\hline
\end{tabular}


G. N. Lazarus and I. Jinad: Forms and usage of indigenous knowledge as tools to improve the quality of life in Idemili South Local Government Area Anambra State, Nigeria

Table 2: Usage of indigenous knowledge

\begin{tabular}{|c|c|c|c|c|c|c|}
\hline Usage of indigenous knowledge & $\mathrm{SA}(\%)$ & $\mathbf{A}(\%)$ & $\mathrm{D}(\%)$ & $\operatorname{SD}(\%)$ & Mean & Std \\
\hline \multicolumn{7}{|l|}{ Agriculture: } \\
\hline I can process and preserve yam. & $148(51.6 \%)$ & $58(20.2 \%)$ & $39(13.6 \%)$ & $42(14.6 \%)$ & 3.0 & 1.111 \\
\hline \multicolumn{7}{|l|}{$\begin{array}{l}\text { Cocoyam, and plantain in dry form and/ } \\
\text { or grind them into flour for traditional } \\
\text { dishes }\end{array}$} \\
\hline $\begin{array}{l}\text { I plant lemon grass to control or expel } \\
\text { termites }\end{array}$ & $122(42.5)$ & $96(33.4)$ & $33(11.5)$ & $36(12.6)$ & 3.0 & 1.021 \\
\hline $\begin{array}{l}\text { I keep maize in the kitchen to dry } \\
\text { moisture content low enough to keep } \\
\text { them safe against weevils }\end{array}$ & $107(37.3)$ & $92(32.1)$ & $43(15.0)$ & $45(15.7)$ & 2.9 & 1.070 \\
\hline $\begin{array}{l}\text { I use wood ash solution on cut surface of } \\
\text { yam sets to avoid decay/rotten and expel } \\
\text { termites }\end{array}$ & $104(36.2)$ & $103(35.9)$ & $24(8.4)$ & $56(19.6)$ & 2.8 & 1.104 \\
\hline $\begin{array}{l}\text { I use dogonyaro leaves(neem) to control } \\
\text { termites on cassava by squeezing the } \\
\text { leaves and sprinkle on the sets with } \\
\text { broom on growing cassava plants }\end{array}$ & $114(39.7)$ & $66(22.6)$ & $53(18.5)$ & $55(19.2)$ & 2.8 & 1.151 \\
\hline $\begin{array}{l}\text { I rub bitter leave juice on the surface of } \\
\text { affected tubers as soon as infestation of } \\
\text { termite is noticed }\end{array}$ & $104(36.2)$ & $77(26.8)$ & $48(16.7)$ & $58(20.2)$ & 2.7 & 1.140 \\
\hline Weighted Mean & & & & & 2.9 & \\
\hline \multicolumn{7}{|l|}{ Traditional medicine: } \\
\hline $\begin{array}{l}\text { Indigenous surgeons combine surgery and } \\
\text { herbs to deliver pregnant women of their } \\
\text { babies }\end{array}$ & $190(66.2)$ & $45(15.7)$ & $36(12.5)$ & $16(5.6)$ & 3.4 & .912 \\
\hline $\begin{array}{l}\text { Making incision on the swollen part of the } \\
\text { body in a bid to get rid of bad water or } \\
\text { blood after which herbs are applied on the } \\
\text { body. }\end{array}$ & $182(63.4)$ & $51(17.8)$ & $21(7.3)$ & $33(11.5)$ & 3.3 & 1.030 \\
\hline $\begin{array}{l}\text { I use obialu-ofuu(scent leaf) and chewing } \\
\text { of } o n u g b u \text { (bitter leaf) to quell stomach } \\
\text { problems }\end{array}$ & $152(53.0)$ & $74(25.8)$ & $19(6.6)$ & $42(14.3)$ & 3.1 & 1.075 \\
\hline $\begin{array}{l}\text { I use plants, herbs, roots, or their } \\
\text { combination for treatment of ailments. }\end{array}$ & $122(42.5)$ & $100(34.8)$ & $23(13.6)$ & $42(14.6)$ & 3.0 & 1.045 \\
\hline $\begin{array}{l}\text { I make use of traditional medicine for } \\
\text { treatment of fever and bone setting } \\
\text { through indigenous orthopedic practices }\end{array}$ & $126(43.9)$ & $78(27.2)$ & $42(14.6)$ & $41(14.3)$ & 3.0 & 1.077 \\
\hline $\begin{array}{l}\text { I use ginger as a spice in cooking food to } \\
\text { prevent vomiting, dizziness, ulcerative } \\
\text { colitis, headaches, fevers and cold }\end{array}$ & $114(39.7)$ & $80(27.9)$ & $56(19.5)$ & $37(12.9)$ & 2.9 & $\begin{array}{l}1.053 \\
.943\end{array}$ \\
\hline Weighted Mean & & & & & 3.1 & \\
\hline
\end{tabular}

Key=Strongly Agree (SA=4) Agree (A=3) Disagree (D=2), Strongly Agree (SD=1) 
G. N. Lazarus and I. Jinad: Forms and usage of indigenous knowledge as tools to improve the quality of life in Idemili South Local Government Area Anambra State, Nigeria

Table 3: Influence of forms of indigenous knowledge usage on the quality of life in Nigeria

\begin{tabular}{|c|c|c|c|c|c|c|}
\hline$\overline{\mathbf{R}}$ & R square & \multicolumn{2}{|c|}{ Adjusted R square } & \\
\hline 0.558 & 0.311 & 0.309 & & \multicolumn{3}{|c|}{$\begin{array}{l}\text { Std. error of the estimate } \\
7446\end{array}$} \\
\hline Variable & $\begin{array}{l}\text { Sum } \\
\text { ofSquare }\end{array}$ & Df & Mean Square & $\mathrm{F}$ & $\mathrm{P}$ & Remark \\
\hline Regression & $\overline{7} 131.76$ & 1 & 7131.76 & \multirow{3}{*}{128.62} & \multirow{3}{*}{0.000} & \multirow{3}{*}{ Significant } \\
\hline Residual & 15802.23 & 285 & 55.44 & & & \\
\hline Total & 22933.99 & 286 & & & & \\
\hline
\end{tabular}

Table 3 presents the result of test of hypothesis focusing on the influence of the forms of indigenous knowledge usage on the quality of life in Nigeria. The result revealed that utilization of indigenous knowledge has significant influence on the quality of life of rural people in Idemili South LGA of Anambra State. The result also shows a coefficient of multiple correlations $(\mathrm{R})$ of 0.558 and a multiple $\mathrm{R}$ square of 0.311 and Adjusted $\mathrm{R}^{2}$ of 0.309 . This implies that $30.9 \%\left(\operatorname{Adj} \mathrm{R}^{2}=0.309\right)$ of the total variance in the quality of life of the rural people (dependent variable) is accounted for by the utilization of indigenous knowledge (independent variable). The significance of the influence was tested at $\mathrm{p}<0.05$ using the F-ratio at the degree of freedom $(\mathrm{df}=1 / 285)$. The table also shows that the analysis of variance (ANOVA) for the regression yielded an Fratio of 128.62 .

\section{Discussion}

The study investigated the forms of indigenous knowledge as tools to improve quality of life in Nigeria under major sectors such as stories, ceremonies and values. Findings revealed folksongs, proverbs, folktales and poetry as the major stories available in the communities under study. Furthermore, in determining the forms of stories available in the study area, it was obvious that there were high percentage availability of indigenous stories in Nigeria. Obi (2010) and Grey (2014) had earlier established poems, poetry, legends and myths as indigenous stories prevalent in rural areas in Nigeria, hence, their studies corroborated the findings from this study.

Traditional marriage, new yam festival, masquerade day, harvest of crop, rituals and wrestling were major forms of ceremonies available to rural people in the study. Also, guides in decision making among the rural people and standard for evaluation of behavior of the rural people were found to be the major forms of values available in the communities under study. Overall, a high level of availability of indigenous values was established by findings from the study. These findings corroborated results from Turner's (2014) study which submitted that values were ideals that give significance and meaning to people's lives and hence underpin their beliefs, influencing the decision they make, the actions they take and the life they lead; and Nnadozie et al's (2015) study which pointed out that human life is held sacred and considered a major value in rural communities, hence murder and suicide amongst its members are seen as anathema.

In addition, the use of indigenous knowledge in Nigeria was considered under major sectors such as agriculture and traditional medicine. Findings on the utilization of indigenous knowledge in 
G. N. Lazarus and I. Jinad: Forms and usage of indigenous knowledge as tools to improve the quality of life in Idemili South Local Government Area Anambra State, Nigeria

agriculture by rural people in communities revealed major areas of indigenous knowledge utilization to include: processing and preserving yam, cocoyam, and plantain in dry form and/or ground-flour for traditional dishes as well as planting of lemon grass to control or expel termites. Also, a high percentage of respondents agreed that they used indigenous knowledge for agriculture in the communities. These findings were in slight contrast with Bamigboye and Kuponiyi's (2010) findings which established utilization of indigenous knowledge in rural areas in Ekiti State, South West of Nigeria, in the areas of land preparation and management. Also, Anaeto et al (2013) reported the idea of rural people dying their chicks for the purpose of protecting them against the attacks of predators as major areas of utilization of indigenous knowledge in agriculture. Therefore, it could be deduced that there were diverse ways of utilization of indigenous knowledge in agriculture in rural communities in Nigeria.

Another area of use of indigenous knowledge investigated by the researcher was in traditional medicine practice in the communities. Findings revealed the combination of surgery and herbs to deliver pregnant women of babies by surgeons, making incision on the swollen part of the bodyin a bid to get rid of bad water or blood after which herbs were applied on the body. It further revealed that using 'obialuofuu'(scent leaf) and chewing of 'onugbu(bitter leaf) to quell stomach problems were among the areas of indigenous knowledge utilization by the rural people. Also, a high percentage of utilization of indigenous knowledge in traditional medicine was also established. Findings from this study was in line with findings from Lwoga, Ngulube and Stlwol's (2010) study that maintained that knowledge of local herbs was normally transmitted in indigenous communities from grandparents to children, especially those who showed interest in such a practice.

The result on the influence of forms of indigenous knowledge usage on the quality of life in Nigeriarevealed that utilization of indigenous knowledgehas significant positive influence on the quality of life of the rural people. It could be deduced that for every level of increase in indigenous knowledge uses in the study area, a $30.9 \%$ improvement in the quality of life of the people would be achieved. These findings corroborated findings from Anyira and Nwabueze's (2010) which established that indigenous knowledge helps Niger Delta rural communities to produce food, acquire education and vocational skills, and conserve their natural environment. It was also in agreement with findings of Ajani, Mgbenka and Okeke's (2013) findings which stated that indigenous knowledge plays a vital role in the quality of life of rural people through design and implementation of sustainable development in production and consumption practices as well as resource conservation and management techniques.

\section{Conclusion}

The importance attached to indigenous knowledge is the only plausible reason for its survival and retention over succeeding centuries. This implies its forms, influence, uses and increasing research interests by scholars of diverse backgrounds. Indigenous knowledge provides an opportunity for communities to be recognized globally with relevant information needed to improve the quality of their lives. Thus, one would expect scholars to view the influence of indigenous knowledge as a positive input in the global knowledge economy and a tool for improving the quality of life of people in 
G. N. Lazarus and I. Jinad: Forms and usage of indigenous knowledge as tools to improve the quality of life in Idemili South Local Government Area Anambra State, Nigeria

Nigeria. The following are recommended in the light of this findings:

1. Libraries and librarians should endeavor to preserve and disseminate IK in the study area which in other words will rekindle interests in indigenous knowledge as a vital research domain for Library and Information Science scholars.

2. In educational level, the Ministry of Education should incorporate indigenous knowledge into the educational curriculum in other to promote the effective usage of the knowledge.

3. Non-Governmental Organization (NGO) and other Not-for-Profit Societies should create sustained awareness of enormous potentials of indigenous knowledge in order to engender better appreciation of the history and culture of people and communities. This suggestion was borne out of the fact that most people have not come to the full realization of the relevance of this specialized knowledge and its positive effects on quality of life.

\section{References}

Ajani, E. N., Mgbenka, R. N., \& Okeke, M. N. (2013). Use of indigenous knowledge as a strategy for climate change adaptation among farmers in Sub-Saharan Africa: Implications for policy. Asian Journal of Agricultural Extension, Economics and Sociology, 2(1), 23-40.

Anaeto, F. C., Asiabaka, C. C., Nnadi, F. N., Aja, O. O., Ajaero, J. O., Ukpongson, M. A., \& Ugwoke, F. O. (2013). Integrating indigenous knowledge system in extension education: The potential for sustainable agricultural development in Nigeria. Research Journal of Agriculture and Environmental Management, 2(11), 332- 340.

Anyira, I. (2010). The role of library in the preservation and accessibility of indigenous knowledge in the Niger Delta Region of Nigeria. Library Philosophy and Practice. Retrieved fromhttp://www.fags.org/periodicals/ 201006/2095013311-html.

Bamigboye, E. O., \&Kuponiyi, F. A. (2010). The characteristics of indigenous system: Influencing their use in rice production by famers in Ekiti State. Ocean Journal of Social Sciences, 3(1), 379-384.

Camfield, L. (2005). Researching quality of life in developing countries. ESRC News Letter.

European Commission. (2015). Quality of life indicators: Measuring quality of life-statistics explained. Retrieved fromec.europa.eu,eurostat,index.php, ou...

Gregory, D., Little, J.,\& Watts, M. J. (2009).Rural geography. In $H$. Gregory, D. Johnson, P. Pratt, G. Watts, \&M. J. Whetmore,(eds.).The dictionary of human geography ( $5^{\text {th }}$ ed).London: Wiley-Blackwell.

Grey, S. (2014). Indigenous knowledge. Retrieved from http://works.bepress.com /samgrey/3/.

Idris, K., Shaffril, H. A. M., Yassin, S., Samah, A. A., Azimi, H., \&Samah, B. A. (2016). Quality of life in rural communities: Residents living near to Tembeling, Pahang and Muar Rivers, Malaysia. PLOS ONE 11 (3):eo150741. Doi:10.1371/Journal.

Inter-Agency Support Group (IASG, 2014). The health of indigenous people.Themetic paper towards the preparation of the 2014 
G. N. Lazarus and I. Jinad: Forms and usage of indigenous knowledge as tools to improve the quality of life in Idemili South Local Government Area Anambra State, Nigeria

worldconference on indigenous peoples. Retrieved from :www.unep/wg/8j/8/inf/12.

Lwonga, T. L., Ngulube, P., \&Stlwil, C. (2010). Managing indigenous knowledge for sustainable agricultural development in developing countries: Knowledge management approaches in the social content. The International Information and Library Review,42(3), 174-185.

Magni, G. (2016). Indigenous knowledge and implications for the sustainable development agenda. Paper commissioned for the global education monitoring report 2016, education for people and planet: Creating sustainable future for all. Retrieved fromgemreport@unesco.org.

Maslow, A.H. (1943). A theory of human motivation.Psychological Review. 50(4), 370-396.

Nnadozie, C. O., Nnadozie, C. D., Ogugua, J. C., Egwim, F. O., \& Ossai-Onah, V. O. (2015). Management of indigenous knowledge in developing countries. Lagos: Zah Communication.

Norudin, M., Zainuddin, Z., \& CheHaspu, R. D. (2013). Quality of life in the $21^{\text {st }}$ century: Narrowing the gap between rural and urban area.
International Journal of Business and Social Science, 4(5), 186-195.

Obi, V. A.O. (2010).The ground work of Oba history. Onitsha: Base-line publishers Ryser, R. C. (2012). Indigenous and traditional knowledge. Encyclopedia of Sustainability, 5, 1-15.

Theofilou, P. (2013). Adherence and physical activity. DOI: http://doi.org/10.4081/hpr.2013.e6

Turner, N. J., \& Clifton, H. (2009). It's so different today: Climate change and indigenous life ways in British Columbia, Canada. Global Environmental Change, 19(2), 180190.

United cities and local governments (UCLG, 2008).Agenda 21 for culture. Barcelonia: UCLG-Committee on culture.

Veenhoven, R. (2010). Life is getting better: Societal evolution and fit with human nature. Socindic Research, 97, 105-122.

World Health Organization (2002).Traditional medicine strategy 2002 2005. Geneva: WHO.

World Health Organization (2005). The World Health Organization Quality of Life Assessment (WHOQOL): Position paper from the World Health Organization. SocSciMed, 4(10), 1403-1409. 